\title{
Work-term Experience and Graduate Attribute Assessment in Software Engineering Co-op Program at University of Ottawa
}

\author{
Aneta George and Liam Peyton \\ University of Ottawa, 800 King Edward, Ottawa, ON, Canada K1N 6N5 \\ atrai062@uottawa.ca, lpeyton@uottawa.ca
}

\begin{abstract}
A successful co-op program is a partnership between university, student and employer. At the University of Ottawa, we have chosen to use an Employer Evaluation form as a critical component of graduate attribute assessment. We also created a new first year course that introduced students to professional communication and responsibility in order to adequately prepare them for their first work term. The graduate attributes from both the coop work experience and the new course are imported into the Graduate Attributes Information Analysis system (GAIA) we have developed. We show the historical trend analysis at both the course level and the program level generated and provide a sample of how we are using these results to guide improvement of our overall program, as well as the co-op experience of students and employers.
\end{abstract}

Keywords: Co-operative Education; Graduate Attributes; CEAB, Accreditation; Assessment Outcomes; Key Performance Indicator.

\section{INTRODUCTION}

\subsection{Motivation}

Cooperative education provides a platform for experiential learning and broadening of professional skills that contribute to the development of graduate attributes that students should possess on graduation. To become a licensed professional engineer in Canada, a candidate must possess an undergraduate engineering degree from a CEAB-accredited program and provide evidence of 48 months engineering work experience [1]. Engineering graduates can enroll in the Engineering Intern Training (EIT) program while they acquire the 48 months of work experience [2]. In addition, up to 12 months of cooperative engineering experience can count towards the 48 months experience when applying for a license from the Professional Engineers of Ontario [3].

COOP education supplements academic knowledge with practical work experience. It is goal-oriented, targeting employment, earnings and a match between job expectations and field of study. The University of Waterloo launched the first COOP program in Canada in 1957. By 2004, 78 Canadian universities offered co-op education with enrollment of almost 78,550 students [4]. Universities Canada reports $50 \%$ growth in co-op programs enrolment for the last decade with more than 100,000 co-op student enrolled in 2015 in about 2,500 coop programs [5]. Results from a 2014 Leger Marketing employer survey for Universities Canada shows $80 \%$ of employers agree that co-op students add value to their businesses as they acquire workplace skills [5].

The Canadian Association for Co-operative Education points out that "co-op students gain employment sooner after graduation, have higher salaries, and are more likely to find employment related to their degree area than nonco-op graduates" [4]. Figure 1 shows the relation between co-op program and non-co-op program in terms of job relation to their field of study.

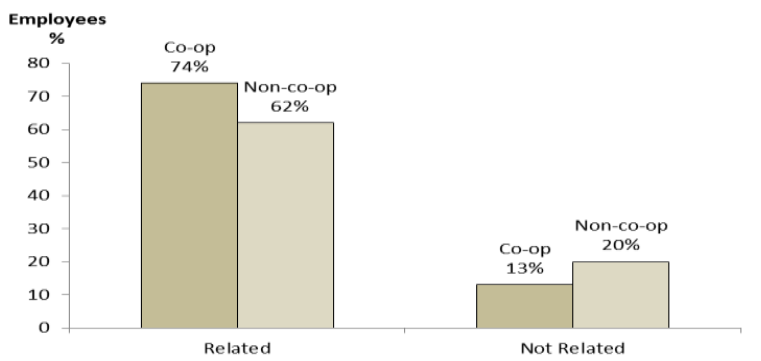

Fig. 1. Relation between job and status of Co-op program.

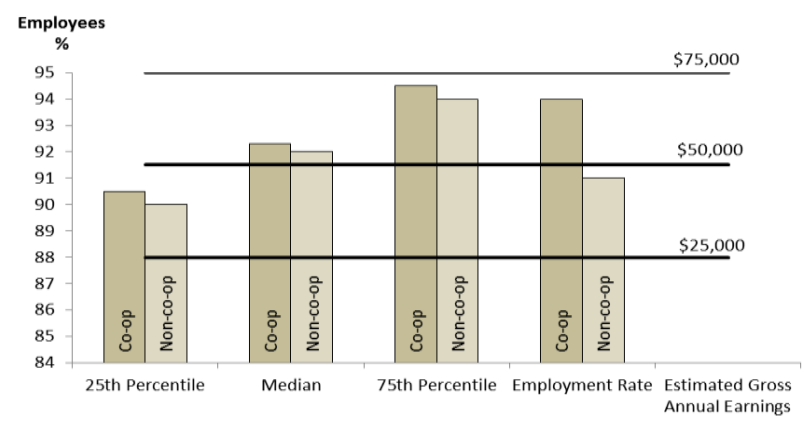

Fig. 2. Estimated annual earnings and Co-op program. 
The relationship between estimated gross annual earnings and co-op/non-co-op bachelor degree is shown on Fig. 2 above.

We use data from Statistics Canada, National Graduates Survey, 2013 (Class of 2009-2010) [6] to generate both graphs. In $2015,55 \%$ of undergraduates benefit from work-integrated learning experience in coops, and internships during their university study [5]. However, students' perception on the university's contribution in developing key employability skills varies. Figure 3 below is generated using data from Canadian Universities Survey Consortium 2015 [7].

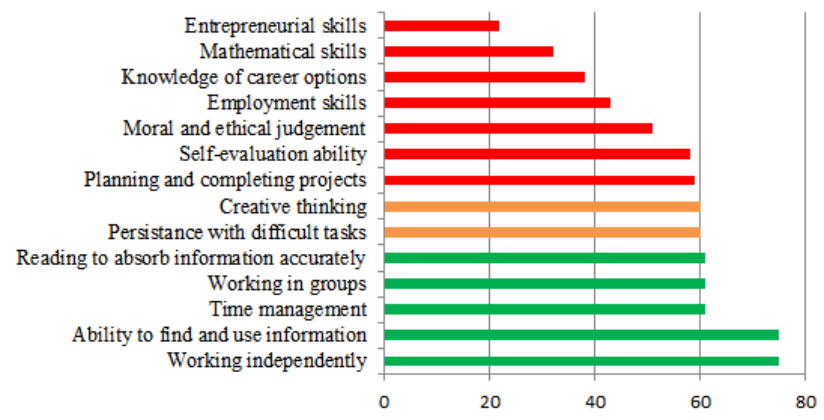

Fig. 3. Students' perception on university contributions.

Universities Canada's Budget 2016 recommendations to the House of Commons Standing Committee on Finance included more "career readiness" opportunities through paid co-ops, internships and mobility experience [5]. It urges support for employer engagement in experiential learning. Software Engineering at the University of Ottawa has had a coop option since it was introduced in 1997 as one of the first software engineering programs in Canada. Since 2014, co-op is a mandatory [8] and we are incorporating employer feedback as part of our graduate attribute assessment process.

\subsection{Literature Review}

In a 1995 article about outcomes for university co-op graduates, Jamie Darch [9] analyses how co-op programs ease the transition from academia to workplace [10]. By referring to findings from 1988 by L.R. Shaw [11], the author gives an insight into the employer viewpoint of COOP to receive inexpensive services from students, replace regular workers on leave, or assess potential employees thus reducing recruitment costs. Darch also points out the benefits for coop students in financing their studies [12].

A steady enrollment rate is good for the reputation of any university, but not producing a large and constantly expanding recruitment pool that does not always reflect the needs of employers. To increase employability of its graduates universities have to work on not only providing a good academic background but developing a highly skilled workforce as well. This issue is a subject of a research conducted by Miriam Weisz [13]. In her study she concludes that employers in our days are more interested in non-degree specific skills when hiring university graduates than their academic results.

In a recent publication Belski, Adunka and Mayer analyze the view of engineering professionals in terms of needed employability skills [14]. They identify that professional, creativity and problem solving skills as more important in work environment than discipline knowledge.

Since 2010, when CEAB started the review of engineering programs toward assessing graduate attributes, some Canadian engineering programs have explored the concept of using employer surveys when evaluating student performance at workplace. Parker, Fondacaro and Nespoli describe the use of a Student Performance Evaluation form implemented by the University of Waterloo. Employer evaluation takes place at the end of each work term and the feedback is used for assessment purposes [15]. A historical trend approach is used to inform program enhancement by using three years co-op work-term data from 12 engineering programs.

The co-op program at the University of Victoria uses a Competency-Based Model to measure academic and workplace experience [16]. M. Gwyn and R. Gupta describe combining the results of two surveys - one administered by the university's Co-op Office and a second one designed for employer's assessment of selected attributes [17]. Employers' evaluation showed a better presentation in knowledge base, ethics and life-long learning compared to economics and project management.

A step "out of the box" is taken by University of Manitoba which is asking "best-in-class" post- graduation engineering employees to identify their own key strengths and weaknesses in the workplace [18]. This was used to develop an assessment strategy for the time their graduates enter the labor market.

McMaster's University School of Engineering Technology reinforces the development of key employability skills by introducing a second year Professional Workplace Practices course as a prerequisite course before students enter the coop work -terms [19]. The course was found to be largely successful in preparing students to complete the mandatory cooperative educational program requirement.

A. M. Coolen discusses the process of developing a co-op work terms curriculum for engineering students, based on the CEAB Engineering Graduate Attributes, that enables students to demonstrate achievement toward four selected graduate attributes [20]. The curriculum was designed and implemented in the Fall 2008 and Winter/Summer 2009 work-terms as a pilot study for a group of 22 students. Assignments include GA self- 
assessment, monthly memos and capstone report writing assessment. Success of the curriculum was measured through a pilot survey involving the 22 pilot-group students, their employers and 259 non-pilot students.

At Memorial University communication, teamwork and leadership, professionalism, ethics and equity and life-long learning skills demonstrated by students at workplace are measured by implementing an e-portfolio approach [21]. Online professional development modules are being involved as part of the e-portfolio.

Student Self-Assessment and Inventory Tool for measuring co-op graduate attributes performance was developed at Dalhousie University [22].

\subsection{Problem Definition and solutions considered}

Integration of co-op work experience implies assessment of graduate attributes through evaluation of learning outcomes from two different sources - academic and workplace. Thus, we identified the need of suitable work-term assessment tool to measure development of graduate attributes at the workplace. To reflect the nature of workplace environment and the need for gathering informative responses lead to using a qualitative data tool. Integrate this with our Graduate Attribute Information Analysis tool (GAIA) required extracting quantitative analysis from qualitative inquiries. This necessitated an add-in to GAIA that would allow processing of qualitative data. The move to mandatory coop in 2014 was another challenge, which required a huge step forward in improving SEG co-op program including the creation of a new course.

\subsection{Significance of the results}

The challenges faced in leveraging the co-op program in assessing student achievement toward CEAB graduate attributes led to improvement of both assessment methodology and graduate attribute information system. This led to the establishment of a new first year course that has proven successful for students, as well as for meeting and exceeding GA program requirements.

\section{ASSESSMENT METHODOLOGY AND DATA ANALYSIS}

\subsection{Employer Evaluation Form}

When assessing co-op students' performance we have identified use of engineering tools (GA 3.1.5), individual and team work (GA 3.1.6), communication skills (GA 3.1.7), professionalism (GA 3.1.8), economics and project management (GA 3.1.11) and life-long learning (GA
3.1.12) as most relevant in terms of their contribution to GA assessment. Evaluation is performed using an Employer Evaluation Form (EEF) exclusively developed for that purpose, by the CO-OP Office at University of Ottawa in consultation with the Software Engineering Graduate Attributes Committee (GAC).

The Employer Evaluation Form (EEF) is designed for employers to record student assessment during a workterm. It lists eleven skills students are expected to demonstrate during their work-term. Employers are evaluating student performance against five-level scale as Exceptional (A+), Excellent (A, A-), Very Good (B+, B), Good $(\mathrm{C}+, \mathrm{C})$, Needs Improvement (D+, D) and Not Satisfactory (E to F). Space is provided for employers to add comments that describe an exceptional gift, ability or specific skill for the workplace task in which a student performed above expectations. Alternatively, this spot is used to comment on the need of further development of particular skill to better match employers needs and expectations. Most of the employers use it to justify the extent to which they rate student performance. Figure 4 shows part of a completed form to illustrate the above.

\begin{tabular}{|c|c|c|c|c|c|c|c|c|c|c|}
\hline Exc. & Exc & lent & Very & food & Goo & & $\begin{array}{l}\text { Need } \\
\text { Impr }\end{array}$ & & $\begin{array}{l}\text { Not } \\
\text { SF }\end{array}$ & N/A \\
\hline At & A & A- & B+ & B & C+ & C & D+ & D & E-F & \\
\hline $\begin{array}{l}\text { Prod } \\
\text { timef }\end{array}$ & $\begin{array}{l}\text { es } \\
\text { ame }\end{array}$ & & eetin & qual & $\exp$ & & wit & & appr & riate \\
\hline & & & & & & & & & & \\
\hline Comr & ents & $\begin{array}{l}\text { Ver } \\
\mathrm{He}\end{array}$ & $\begin{array}{l}\text { notiva } \\
\text { led ta }\end{array}$ & 1, not & raid $t$ & & & & & \\
\hline Demo & strat & effe & ve an & esou & eful $p$ & blen & olving & & & \\
\hline & & & & & & & & & & \\
\hline Comr & ents & Ap & d Jav & $\mathrm{X}, \mathrm{r}$ & arche & anc & gured & ho & o use i & \\
\hline Show & inter & $t$ in & rk tas & & & & & & & \\
\hline & & & & & & & & & & \\
\hline Comr & ents & $\mathrm{Me}$ & oned 1 & is lea & ng a 1 & & & & & \\
\hline Appli & s tecl & ical/ & entifi & heor & cal co & epts & tasks & & & \\
\hline & & & & & & & & & & \\
\hline Comr & ents & $\begin{array}{l}\mathrm{CS} \\
\text { thin }\end{array}$ & $\begin{array}{l}\text { Id SE } \\
\text { hrou }\end{array}$ & love & $\begin{array}{l}\text { cod } \\
\text { umer }\end{array}$ & & hould & & & think \\
\hline
\end{tabular}

Fig. 4. EEF. Skills evaluation.

Figure 5 shows the section located at the end of EEF document where employers outline identified strengths and areas for development to inform improvement of student work-place performance. Students can view this evaluation in their COOP Navigator account.

\begin{tabular}{|c|c|c|}
\hline & \multicolumn{2}{|c|}{$\begin{array}{c}\begin{array}{c}\text { Employer's comments on the student's strengths and areas for } \\
\text { development }\end{array}\end{array}$} \\
\hline & Strengths & Areas for development \\
\hline 1. & Strong software skills & 1. Design skills \\
\hline 2. & Researching, self-learning & 2. \\
\hline
\end{tabular}

Fig. 5. EEF. Strengths and areas of development. 
The goal of a work-term evaluation is to contribute to student development, but we use the same data to measuring CEAB graduate attributes. The EEF is mapped to Key Performance Indicators (KPIs). Table 1 shows the GA map to measure individual and team work (GA 3.1.6), communication skills (GA 3.1.7), professionalism (GA 3.1.8) and life-long learning (GA 3.1.12).

Table 1: Co-op GA/KPI map.

\begin{tabular}{|l|c|c|}
\hline \multicolumn{1}{|c|}{$\begin{array}{c}\text { Skill Evaluated by } \\
\text { Employer }\end{array}$} & $\begin{array}{c}\text { Skill } \\
\text { Number } \\
\text { in EEF }\end{array}$ & $\begin{array}{c}\text { Related } \\
\text { KPI }\end{array}$ \\
\hline $\begin{array}{l}\text { Produces work meeting } \\
\text { quality expectations within an } \\
\text { appropriate timeframe }\end{array}$ & S.1 & $\begin{array}{c}\text { GA 3.1.8 } \\
\text { (KPI 8d) }\end{array}$ \\
\hline $\begin{array}{l}\text { Demonstrates effective and } \\
\text { resourceful problem solving } \\
\text { skills }\end{array}$ & S.2 & $\begin{array}{c}\text { GA 3.1.12 } \\
\text { (KPI 12a) }\end{array}$ \\
\hline $\begin{array}{l}\text { Shows interest in work tasks } \\
\text { Applies } \\
\text { technical/scientific/theoretical } \\
\text { concepts to tasks }\end{array}$ & S.4 & $\begin{array}{c}\text { GA 3.1.12 } \\
\text { (KPI 12e) }\end{array}$ \\
\hline $\begin{array}{l}\text { Demonstrates a professional } \\
\text { work ethic }\end{array}$ & S.5 3.1.12 & $\begin{array}{c}\text { GA 3.1.8 } \\
\text { (KPI 8e) }\end{array}$ \\
\hline Works well in a group & S.6 & $\begin{array}{c}\text { GA 3.1.6 } \\
\text { (KPI 6b) }\end{array}$ \\
\hline Works well independently & S.7 & $\begin{array}{c}\text { GA 3.1.6 } \\
\text { (KPI 6a) }\end{array}$ \\
\hline Shows dependability & S.8 & $\begin{array}{c}\text { GA 3.1.8 } \\
\text { (KPI 8g) }\end{array}$ \\
\hline $\begin{array}{l}\text { Is receptive to and integrates } \\
\text { feedback }\end{array}$ & S.9 & $\begin{array}{c}\text { GA 3.1.8 } \\
\text { (KPI 8f) }\end{array}$ \\
\hline Communication skills: Verbal & $\begin{array}{c}\text { GA 3.1.7 } \\
\text { (KPI 7e) }\end{array}$ \\
\hline Communication skills: Write & $\begin{array}{c}\text { GA 3.1.7 } \\
\text { (KPI 7f) }\end{array}$ \\
\hline
\end{tabular}

\subsection{GAIA}

All co-op assessment data collected through courses and COOP work-terms was recorded into GAIA and processed to produce three types of reports:

- Type I is a historic trend of co-op GA assessment measured against Meet/Exceed program requirements criteria ( $60 \%-80 \%$ scale). Figure 6 below shows a sample graph of this type.

- Type II is an assessment scale distribution per GA per course/work-term per academic year. We use a four-level scale (Exceed Expectations, Meet Expectations, Marginal and Insufficient) with respective boundaries at 55\%, 80\% and 90\% (see Fig. 7 below).
- Type III is a historic trend of an assessment scale distribution per GA (respective KPI) (see Fig. 8). The graphs use sample data and are generated for the purpose of this paper.

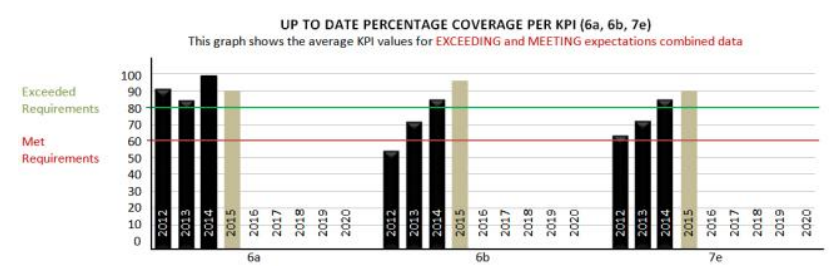

Fig. 6. GAIA Type I report.

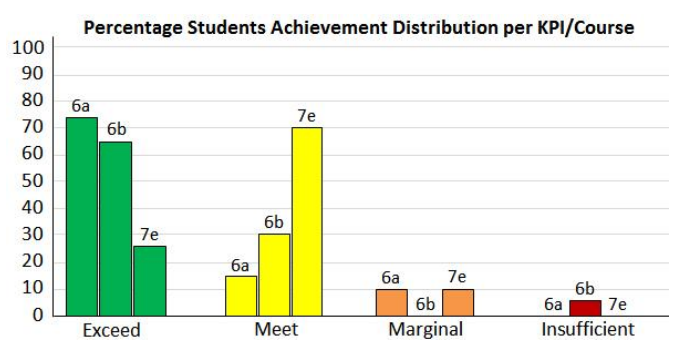

Fig. 7. GAIA Type II report.

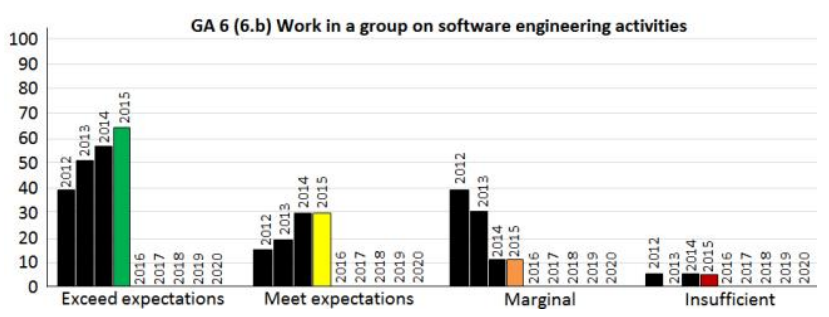

Fig. 8. GAIA Type III report.

GAIA also produces a numerical historic trend of GA assessment per course. Such type of report can accommodate KPI data collected using different courses. It proved evidence of records for accreditation visiting team; helps inform program improvement and identify areas for development.

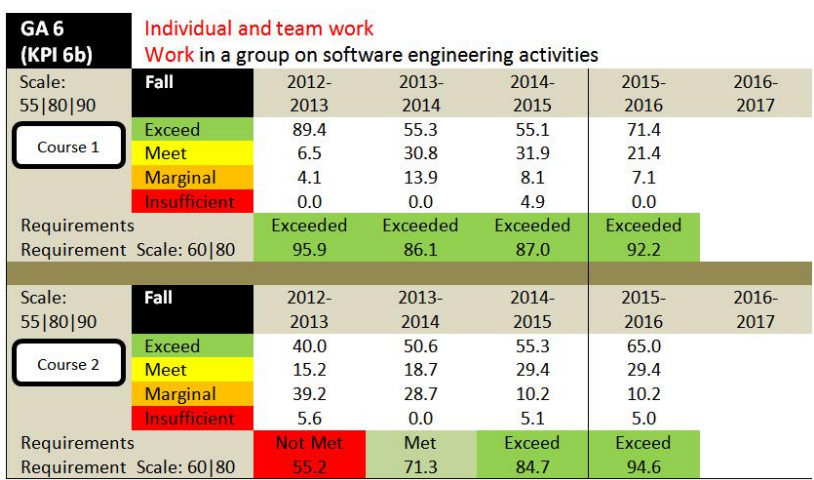

Fig. 9. GAIA Numeric historic trend of GA record. 
The sample report shown on Fig. 9 illustrates numerical historic data trend for particular KPI that was assessed by two different courses.

\subsection{Sample Program Improvement}

In order to better accommodate employers' expectations and improve students' work-term performance, a new course SEG1911 Professional Communication and Responsibility, has been created for the Software Engineering (COOP) program. The course is an introduction to the responsibilities of software engineers to their employer, their profession and public safety, with emphasis on the development of skills in oral and written communication. Students practice presentations and writing technical reports, business letters, web pages, and safety guidelines. Introduction to source code management and version control is also covered.

The need for this course was driven by feedback from employers and the COOP office as well as a KPI for graduate attribute 8 Professionalism, as it was measured in first year as students prepared and attempted to secure a job for their first work-term. An agreed by the program Graduate Attributes Committee measurement criteria for exceed, meet, marginal and insufficient achievement for the KPI is determined as follows:

- Exceeded expectations - job secured in first round of COOP interviews for first work term at end of year one.

- Meet expectations - job secured with supplemental help after first round.

- Marginal achievement- students interviewed but were unable to find a job

- Insufficient - students not allowed to interview because they are on academic probation.

The course addresses communication skills, professional skills, and software engineering culture and experience that were identified as lacking. It also fostered teamwork and a sense of professional community and professional development that were applied to improving academic results as well. First year university is a year of transition for students, and the same skills that better prepared them for coop were also relevant to academic studies.

The course was piloted this year, and early results show immediate improvement. The COOP office, employers, and the software engineering student society are all seeing noticeable improvements. The percentage of students on academic probation has gone from $33 \%$ to $22 \%$ and the number of students placed in the first round went from $22 \%$ to $39 \%$.

\section{CONCLUSIONS}

We have been successful in integrating performance measurements from COOP work experience into assessment of graduate attributes as set by CEAB [7]. In particular, we were able to improve our GAIA tool by adding support for generating quantitative outcomes from qualitative inquiries.

We established a procedure for CO-OP program review with consultation of appropriate stakeholders, including the COOP office and key employers, leading to continual improvement of the program. This led to the creation of a new course, SEG1911 Professional Communication and Responsibility, to better prepare students for success in their careers in the workplace. This includes measuring the quality of pre-graduation co-op work experience against five quality-based PEO criteria.

Among the major advantages of the proposed assessment technique is the fact that the process does not require a substantial amount of effort or time to implement. GAIA reduces the amount of administration work required to organize, process and analyze the assessment data. It improves visualization of the results and produces easy to read outcomes-based analyzed tables and graphs. The system leverages existing feedback mechanisms for work-term performance thus making it easy to use, process and analyze.

\section{Acknowledgements}

The work was supported by both the Faculty of Engineering and the COOP Team at the University of Ottawa, as well as NSERC. We would especially like to thank Marc-André Daoust for his partnership and support.

\section{References}

[1] Professional Engineers Ontario, Licensing Guide and Application for Licence. Published by Association of Professional Engineers of Ontario, Toronto, June, 2012, 15 pp,. Available as of Apr. 19, 2016 from

http://www.peo.on.ca/index.php/ci_id/14824/la_id/1.htm

[2] Professional Engineers Ontario, The Engineering Intern (EIT) Program, 2016. Available as of Apr. 19, 2016 from http://www.peo.on.ca/index.php/ci_id/2064/la_id/1.htm

[3] Professional Engineers Ontario, Guide to Require Experience for Licensing as a Professional Engineer in Ontario, Published by Association of Professional Engineers of Ontario, Toronto, February 8, 2013, 10 pp. Available as of Apr. 19, 2016 from http://www.peo.on.ca/index.php/ci_id/22929/la_id/1.htm

[4] Canadian Association for Co-operative Education (CAFCE), Cooperative Education Manual - A Guide to 
Planning and Implementing Cooperative Education Programs in Post-Secondary Education, CAFCE, Toronto, Available as of Apr. 19, 2016 from

http://www.cafce.ca/_Library/_documents/coopmanual.pdf

[5] Universities Canada submission to the House of Commons, Universities: Empowering Canadians, Empowring Communities, Universities Canada, Ottawa, 2016, Available as of Apr. 19, 2016 from http://www.parl.gc.ca/Content/HOC/Committee/421/FINA/ Brief/BR8095001/br-external/UniversitiesCanada-e.pdf

[6] S. Ferguson and S. Wang, Graduating in Canada: Profile, Labor Market Outcomes and Student Dept of the Class of 2009-2010, Statistics Canada, 4, Nov. 14, 2014, pp.67. Available Apr. 19, 2016. http://www.statcan.gc.ca/pub/81595-m/2014101/section03-eng.htm

[7] Canadian University Survey Consortium, 2015 Graduating University Student Survey Master Report, Prairie Research Associates. Available Apr. 19, 2016. http://www.cuscccreu.ca/CUSC_2015_Graduating_Master\%20Report_Engl ish.pdf

[8] University of Ottawa, Strategic Enrollment Management, 2014. Available as of Apr. 19, 2016 from http://www.uottawa.ca/academic/info/regist/calendars/progr ams/1593.html

[9] J. Darch, "Labour market outcomes for university co-op graduates," Perspectives (Montclair), Statistics Canada Catalogue 75-001E Quarterly, Vol. 7, No. 3, pp. 20-24, Autumn, 1995. Available as of Apr. 19, 2016 from http://www.statcan.gc.ca/pub/75-001-x/1995003/1638eng.pdf

[10] D. Rayan, "Co-op plans may ease education woes," Calgary Herald, Issue: September 29, 1992:A5.

[11] L. R. Shaw, "Co-operative education: good for business, good for Canada.," Canadian Speeches 2, no. 5, August September, 1988, pp. 17-20.

[12] Association of Universities and Colleges of Canada, "Coop students value money, job experience," University Affairs,31, no. 7, August-September, 1990, p. 34.

[13] M. M. Weisz, "The Added Value of Undertaking a Cooperative Education Year: The Measurement of Student Attributes," Assessment, 2000. Available Apr. 19, 2016 from http://www.waceinc.org/papers/Weisz_7_27_00.pdf

[14] I. Belski, R. Adunka, O. Mayer, "Educating a Creative Engineer : Learning from Engineering Professionals", Procedia CIRP, Vol. 39, 2016, p. 79-84.

[15] W. Parker, R. Fondacaro, O. Nespoli, "Employing Co-op Employer Evaluations to Assess Outcomes", in Proc. CEEA Canadian Engineering Education Conf., CEEC11, (St. John's, NL; 6-8 June 2011).
Available as of Apr. 19, 2016 from

http://library.queensu.ca/ojs/index.php/PCEEA/article/view 13611

[16] University of Victoria, Putting Learning in Motion, Cooperative Education program and Career Services. Available as of Apr.19, 2016 from http://www.uvic.ca/coopandcareer/employers/home/student skills/index.php

[17] M. L. Gwyn and R. Gupta, "Coop Employer Evaluation of the Graduate Attributes: A Comparison of two approaches" in Proc. CEEA Canadian Engineering Education Conf., CEEC15, (Hamilton, ON, May 31-June 3, 2015), 5 pp., 2015. Available as of Apr. 19, 2016 from http://library.queensu.ca/ojs/index.php/PCEEA/article/view 15788/pdf

[18] K. Ferens, "External Assessment of Engineering Programs," in Proc. CEEA Canadian Engineering Education Conf., CEEC12 (Winnipeg, MB; 17-20 June 2012), 4 pp., 2012. Available as of April 19, 2016 from http://library.queensu.ca/ojs/index.php/PCEEA/article/\%20 view/4670/4652

[19] A. MacKenzie, "A Retrospective: Designing a Career Development Preparation Course in a Mandatory Coop EngineeringTechnology Program", in Proc. CEEA Canadian Engineering Education Conf., CEEC15, (Hmilton, ON; May 31-June 3, 2015), 8 pp., 2015. Available April 19, 2016 from http://library.queensu.ca/ojs/index.php/PCEEA/article/view 15771/pdf

[20] A. Coolen, "Implementing a CEAB Engineering Graduate Attributes Based Co-op Work Term Curriculum", in Proc. CEEA Canadian Engineering Education Conf., CEEC11, (St. John's, NL; 6-8 June 2011), 6 pp., 2011. Available as of Apr. 19, 2016 from

http://library.queensu.ca/ojs/index.php/PCEEA/article/view /3646/3659

[21] Darlene Spracklin-Reid, "Teaching and Assessing Graduate Attributes in Cooperative Education," in Proc. CEEA Canadian Engineering Education Conf., CEEC14, (Calgary, AB; 8-11 June 2014), 1 pp., 2014. Available as of Apr. 19, 2016 from http://library.queensu.ca/ojs/index.php/PCEEA/article/view $15900 / 5622$

[22] EGAD Project Group, Graduate Attributes Self-Assessment and Inventory Tool, adapted from material contributed by Engineering and Computer Science, Dalhousie Univ. Available as of Apr. 19, 2016 from http://egad.engineering.queensu.ca/wpcontent/documents/GASelf-Assessmentedited.pdf 